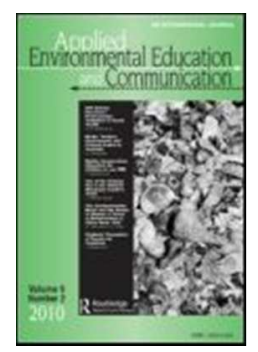

\title{
Young people and greenhouse gas emissions at music festivals
}

\begin{tabular}{|r|l|}
\hline Journal: & Applied Environmental Education \& Communication \\
\hline Manuscript ID & UEEC-2017-0069.R1 \\
\hline Manuscript Type: & Research Article \\
\hline Keywords: & Climate change, Peer education, Music festivals, Young people \\
\hline Abstract: & $\begin{array}{l}\text { Young people are major players in implementing long term climate policy } \\
\text { goals. This paper describes how, for over ten years, young people as peer } \\
\text { educators have been engaging with both festival goers and festival } \\
\text { organisers to help reduce their greenhouse gas emissions, though the } \\
\text { "Face Your Elephant" interactive public engagement exhibition. } \\
\text { The innovative approach trained and worked with over a hundred young } \\
\text { peer educators. It engaged with over 10,000 festivalgoers helping them to } \\
\text { take action to reduce their carbon footprint in an exciting way, through an } \\
\text { exhibition at a music festival }\end{array}$ \\
\hline
\end{tabular}


Reviewer 1

1. The surveys, based on the information reported in Table 1, seem to be a qualitative survey. It is important to note the limitations of a cross-sectional study. You state the survey was quantitative in nature. This is not clear to the reader as no data is presented other than attendees at various music festivals. ADJUSTED TABLE 1 TO INCLUDE NUMBERS, MOVED TABLE 1 TO NEARER TO THIS SECTION AND ADDED TEXT ON OTHER DATA COLLECTED

2. Including the survey as an Appendix would be useful for those who wish to replicate your work. INCLUDED TWO SURVEYS AS APPENDIX A AND B

3. Peer education is the main method by which to convey the message of energy conservation and climate change. More information is needed on how peers were identified and trained. ADDED TEXT IN THE KEY CONCEPTS SECTION

4. The theory section of the manuscript seems to be an "add-on". The findings should be presented in light of the theories you state were implemented. RESTATED OUR OVERALL OBJECTIVE OF THE PAPER IN METHODS SECTION

5. Describe the implications of the findings of this work on environmental education efforts at large music festivals. Will policy result from this peer education model? TEXT ADDED IN CONCLUSIONS

6. You mention partnerships are an important component required for this work. Briefly describe the partners and the development of a partnership. TEXT ADDED IN PROJECT DEVELOPMENT

7. Describe the future directions of this work and are the findings generalizable to other areas that engage environmental education? EXTRA TEXT ADDED IN THE CONCLUSIONS

Reviewer: 2

Comments to the Author

The methods section still needs to be developed further. In the methods section, please report $n=$ for the different data sets you reference and provide more information about what primary data was collected and how it was collected. - ALTERED TABLE 1 AND CHANGED POSITION

Were photos/videos used as artifact data? (p. 6 line 18) If so, further describe what this is and how it was collected. - REMOVED THIS, WE DID USE IT TO A LIMITED DEGREE BUT THERE IS NOT ENOUGH SPACE TO WARRANT EXPLAINING THIS FURTHER.

Also, $\mathrm{Pg} 3$ line 47 requires a reference. - DONE 


\title{
Young people and greenhouse gas
}

\section{emissions at music festivals}

\begin{abstract}
The findings of "Face your elephant", a peer led youth engagement project are presented. This has been operating for over 10 years and has engaged with over 10,000 festival goers at 15 festivals, trained over 100 peer educators in science communication and public engagement skills and helped to change power supply practices of festival organisers in the UK. This long term approach has delivered multiple benefits in terms of raising festival goers awareness of actions needed to address climate change, empowering young volunteers as peer educators and informing festival organisers about the opportunities for greenhouse gas emission reductions.
\end{abstract}

Keywords: Climate change, Peer education, Public engagement, Greenhouse gas emissions, Energy efficiency, Outdoor events, Temporary electricity, Off grid, Smart grid, Environmental education

\section{Introduction}

The project name, "Face Your Elephant" refers to the average UK citizen's annual carbon footprint which is roughly equivalent to the weight of two adult elephants (around 10 tonnes in 2006). The approach combined the peer education experience of national youth charity The Woodcraft Folk with the research outcomes of the Institute of Energy and Sustainable Development at De Montfort University and the visitor engagement activities of the Centre for Alternative Technology. Young 
peer educators engaged with audiences around the complex issue of climate change in the informal leisure setting of a music festival.

The Climate Change Act 2008 has committed the UK to an overall reduction of $80 \%$ of $\mathrm{CO}_{2}$ emissions, by 2050 , from the 1990 baseline. Many industries have adopted targets, including the music industry. 3.9 million people are estimated attend music festivals in the UK (UK Music, 2017) and in 2007, annual greenhouse gas emissions from the UK Music industry as a whole were estimated at 540,000 tonnes (Bottrill, 2007). The impact of festivals on the natural world is being addressed in the UK by non-profit organisations such as Julie's Bicycle, A Greener Festival and EEMusic in Europe. Each has developed award schemes related to reducing emissions at festivals and major events. The development of ISO20121 for Sustainable Events Management has further raised awareness. Many organisers agree that achieving these standards results in economic and environmental savings as well as brand or prestige benefits (International Standards Organisation, 2013). One survey showed $28 \%$ of audiences claim to consider a festivals environmental impact when choosing to attend and $43 \%$ claim to have changed their behaviour as a result of green initiatives they had encountered at festivals (Challis, 2013)

Academic literature on the environmental impact of festivals and events is increasing. In 'Nature and scope of festival studies' (Getz, 2010), of the 423 research articles reviewed, only one was found that focused on environmental impacts. The same year saw the publication of 'Sustainable Events Management' (Jones, 2010) the first textbook on the topic, with the second edition including further detail on energy consumption (Jones, 2014). The 'Power Behind Festivals' report (Johnson et al., 2013) specifically covered temporary off grid electricity supply for outdoor events, building on electricity monitoring work carried out at UK festivals (Fleming et al., 2014). More detailed carbon footprint assessments have also been undertaken at Shambala festival (Harper, 2010) and the wider field of events management has aimed to become more holistic in its approach, incorporating measures across environmental, social and economic domains (Fletcher, 2013) (Donovan, 2013). The 
London 2012 Olympics, as a leading mega-event (Müller, 2015), was a key driver towards the establishment of ISO20121 and Arts Council England, in 2012, became the first arts funding body in the world to require regularly funded organisations to measure and act on their environmental impacts.

The charity Julie's Bicycle has collected data from festivals since 2011 and produces a set of environmental benchmarks for festivals to compare their performance against (Julie's Bicycle, 2014). In Bottrill's 2007 estimation, generators were identified as contributing 20,000 tonnes of $\mathrm{CO}_{2} \mathrm{e}$ around 4\% of the total UK Music Industry emissions (Bottrill, 2007). Emissions from diesel generators are commonly the largest source of on-site emissions at festivals and the details of electricity use at outdoor events is an area that is not widely understood even among events professionals. The benchmark for festivals ${ }^{1}$ is currently in its third revision with a target of $2.3 \mathrm{~kg} \mathrm{CO}_{2}$ e emissions per audience-day ${ }^{2}$. For a typical three-day festival $(6.9 \mathrm{~kg})$, these emissions can be conceptualised as the equivalent of each attendee driving a medium sized car for around 16 miles (Department for Business, Energy \& Industrial Strategy, 2016).

Face Your Elephant emerged at the intersection of these issues, engaging with people to communicate actions they could take to reduce greenhouse gas emissions, for audiences and organisers alike.

\section{Methods}

It is relatively challenging to operate public engagement projects over a long period of time. Funding bodies often want to support new initiatives rather than provide continuation funding to existing projects. Face Your Elephant received funding from different bodies, with slightly different

\footnotetext{
${ }^{1}$ The benchmark is based on data from 13 festivals. All except one were under 20,000 attendance in size. The benchmark excludes audience transport but includes diesel use for generators, landfilled waste and emissions related to water supply and sewerage.

${ }^{2} 1$ audience day is equal to 1 person visiting the festival for 1 day. E.g. 1 person attending a festival for Friday, Saturday and Sunday $=3$ audience days.
} 
approaches over the years. However, the key feature throughout continued to be young peer educators engaging with young audiences, supported by advice and guidance from academic and communication experts. The project typically concentrated its practical activities within a 2-3 month summer period each year although ongoing communications and research continued beyond this. Throughout the project, a variety of data were collected for short term feedback and evaluation. Over several years this built up a degree of continuity around peer education and working with festival organisers to help them achieve greenhouse gas emissions reductions. A synthesis of these individual reports, evaluations and papers has been used to describe the key themes relevant for other peer education or public engagement projects.

Festival-goers experiences were collected through quantitative surveys collected directly after their engagement with the exhibit. A smaller amount of festival-goers also completed a detailed carbon calculator estimating their personal emissions. The experience of peer educators was collected through quantitative surveys completed at pre-and-post training events. In addition, minute by minute data from electricity generators was collected through either installing data loggers or accessing the generator providers' online monitoring data. Stallholders and traders at the festival were interviewed in later years by peer educators. Although these latter two sources of data were central to the projects overall aims and were used to inform exhibit displays and fed back to event organisers, the full detail is not included in this paper $^{3}$ due to the focus on peer education and public engagement. Interviews, photo and video records, comment cards, face to face discussions, graffiti walls and other methods were also used to engage with people and collect data. Table 1 summarises the events attended and survey data collected.

<Insert Table 1 here>

\footnotetext{
${ }^{3}$ This detail on electricity related emission can instead be found in 'Electricity-related GHG emissions at offgrid, outdoor events' (Fleming et al., 2014)
} 


\section{Project development and funding}

The project was developed as a partnership between the Woodcraft Folk, The Centre for Alternative Technology and De Montfort University to engage young people, in a non-school, leisure environment, with practical activities that are fun and that also help reduce greenhouse gas emissions. The activities began with an Energy Saving Trust project as part of the 2001 Woodcraft Folk International Festival in Walesby, Nottinghamshire. Over 5,000 people participated in a twoweek long event with Woodcraft Folk volunteers (ages 5 to 25 ) involved in activities such as building solar electricity systems and solar showers (Harper, 2016). Grants from Awards For All and the Scottish Executive enabled young people to design and build two solar energy trailers; the 500W eco-trailer in Leicester and the 1,000W Powerpod in Edinburgh. Both provided light and power for a range of Woodcraft Folk events.

The Global Village Festival was a two-year project delivering fun, energy-related activities at the twoweek Woodcraft Folk festival that took place in 2006 with 4,500 young people (ages 5 to 25) attending. This was funded by the Engineering and Physical Sciences Research Council (ref: EP/C006429/1). The Festival used the Millennium Development Goals as a focus, specifically: "To increase the awareness and understanding of young people to the actions that they can take to improve environmental sustainability". Practical activities included building solar water heaters and thermal storage, solar electricity systems, wind turbines and electrical storage.

The C-Change project, part of the Department for Environment, Food and Rural Affairs (DEFRA) Climate Challenge Fund, was led by Woodcraft Folk volunteers (ages 11 to 21) with the Centre for Alternative Technology and De Montfort University to deliver a series of engagement events that appealed to young people. This included theatre events, club nights, an exhibit at Woodcraft Folk events and an exhibition at Glastonbury Festival in 2007 (Harper, 2016). The young people involved saw the music festival element as one of the most effective parts of the C-Change project, as it was easier to engage with people one-to-one, in a leisure environment. 
Further EPSRC support was secured to deliver this project at music festivals from 2009-2011, (ref: EP/G064458) with the support of festival organisers ${ }^{4}$. This led to monitoring and evaluation of electricity consumption of diesel powered electricity generators, (Marchini, 2013) and a Knowledge Transfer Partnership with the festival power supply company Midas UK from 2012-13. Ingenious funding, from the Royal Academy of Engineering (RAEng) enabled the project to continue with more of a focus on the role of engineering and smart grids in $2014-15$.

\section{Key concepts}

Social Cognitive Theory (SCT) (Bandura, 1986) gives a relevant theoretical basis for the efficacy of Face Your Elephant in peer education and public engagement. This approach was based on the successful Woodcraft Folk work on Mediation Education Support Training Umbrella Project or MESTUP that has successfully operated at Woodcraft Folk events since the 1990s. Peer educators typically staff a tent with information, books and leaflets where young people can relax and chat while also addressing more serious subjects such as relationships, drugs and peer pressure. The engagement between peers in Face Your Elephant can be described as peer collaboration, high in both equality and mutuality: "[approaches that] seem most likely to generate productive instructional dialogues...encourage joint problem solving, rely on intrinsic rather than extrinsic rewards, and that discourage competition between students" (Damon \& Phelps, 1989).

The Face Your Elephant approach built on this experience and worked with young people to engage with their peers and audience members around the actions that they could take to reduce their personal emissions. In earlier years of the project, the peer educators were typically members of the Woodcraft Folk. In later years, the young peer educators also included students from a range of institutions and specifically, in 2014-15, this included a larger number of engineering students. In keeping with Damon \& Phelps definition of peer collaboration, the approach was effective

${ }^{4}$ Festival organisers involved were: Festival Republic (Latitude), Leicester City Council (Big Session and Summer Sundae) and Kambe Events (Shambala). 
throughout with all peer educators, from different backgrounds, engaged in the project. Training took place via residential training weekends and practical workshops before the events and morning and evening briefings at the events themselves.

Public engagement in the UK has been shaped by the view that: "Direct dialogue with the public should move from being an optional add-on... and should become a normal and integral part of the [research] process." (House of Lords Select Committee on Science and Technology, 2002). Face Your Elephant fitted this general model of public engagement, whereby specialists interact with nonspecialists, in this case, academics interacting with the general public in order to affect behaviour change.

The theoretical approach to addressing behaviour change includes the theory of planned behaviour (Ajzen, 1991), the theory of interpersonal behaviour (Triandis, 1977) and value-belief-norm theory (Stern et al., 1999) based on norm activation theory (Schwartz, 1977). This suggests that environmentally significant behaviour is influenced by a complex combination of variables. These variables fall into four broad categories: attitudinal factors (such as norms, beliefs and values); contextual forces (such as available time, monetary cost and availability of resources); personal capabilities (which include skills and knowledge); and habits, (Stern, 2000a). The influence of each of these varies depending on the behaviour in question (Gardner \& Stern, 1996) (Stern, 2000b). This body of research also shows that while attitudes are one of the antecedents of behaviour, nevertheless there are inconsistencies between a person's attitudes and their behaviour, which has also been discussed in the literature (Fahy, 2005) (Kollmuss \& Agyeman, 2002). This mismatch has been referred to as the value-action gap (Barr, 2006) and as Stern highlights, "studies that examine only attitudinal factors are likely to find effects only inconsistently, because the effects are contingent on capabilities and context" (Stern, 2000a, p. 418). Therefore the Face Your Elephant exhibit would play to the strengths of the environment it was situated in and take into account the underlying attitudes of the audience. Put simply, young people at music festivals were more likely to 
be reached by an exhibit developed by, and staffed with, other young people to fit with the environment, types of activities and relevant information for a music festival.

\section{Findings}

Taking climate change as a central topic required a multi-disciplinary approach. The combination of peer education experience (Woodcraft Folk), research expertise (De Montfort University) and engagement skills (Centre for Alternative Technology) provided the multi-disciplinary approach necessary to work with young people. The level of technical knowledge required by the peer educators varied and different science and engineering specialisations were represented from energy, automotive, civil and mechanical engineering to associated fields such as design and environmental management.

The Peer Educators had to be enthusiastic to talk to their peers about relatively complex science and engineering subjects and how this relates to day-to-day life. Their role incorporated catching and maintaining the attention of festival-goers, to teach and sell the benefits of actions to festival-goers. Their work included low-commitment tasks like setting up solar toys, giving out free pedal powered smoothies or solar phone charging. Challenging and high-commitment tasks included constructing the marquee and display materials, programming a carbon calculator tool and giving short structured seminars. The approach was successful with many peer educators returning over a number of years. Some themes the peer educators noted from their own evaluations are summarized in Table 2 below:

<Insert Table 2 here>

The key aim for all peer educators was to have detailed communications with festival goers. This moved beyond general discussion into specific discussion of actions related to personal or national carbon reduction opportunities. This required reference to national energy policy, to research 
findings from the UK Energy Research Centre, Zero Carbon Britain and included festival-specific discussions centred on hybrid generator performance, demand response and smart grids.

One to one interviews were carried out with peer educators (Wall, 2010) to evaluate their experiences. The central factor identified in the project's success was a "Sense of belonging and support" which linked to: "Integration of knowledge into engagement activities", "Creative freedom in delivery" and "Developed relationships with peers". The peer educators at this time were mostly Woodcraft Folk members, so we might assume their relationships may be pre-established and not unique to the project. However, during later stages of the project, 2014-15, fewer of the volunteers were Woodcraft Folk members and these positive features were still reported by peer educators in post-training evaluations ( $n=32$ ). $86 \%$ agreed they had a sense of ownership of the project and $72 \%$ agreed they had improved their ability to come up with creative solutions.

The overall volume of public engagement varied, with the project expanding to larger events over time. At larger festivals of 30,000 or more people, it was possible to engage with about 1,500 people in a weekend. At smaller events $(500-5,000)$ the project would be able to engage $500-1,000$ people; in some cases, practically the whole audience. At one festival of 7,000 people, $17 \%$ of the general audience recalled that they had visited Face Your Elephant, when completing a separate survey about their wider experience (Maughan \& Fletcher, 2010). However, the project aimed to focus on quality and length of engagement over volume. A team of 20 peer educators staffed the exhibit, inside and out, at any one time, therefore there was an upper limit of around 30-40 festival goers being engaged at any one time. An average day would see around 300 long (around 10 minutes) engagements and double this amount of short (under 10 minutes) engagements. The exhibit was typically open for 8 hours per day, from $11 \mathrm{am}-7 \mathrm{pm}$. The exhibit also attracted a number of experts from the general population at the festivals, particularly utilities workers, energy engineers and postgraduate students. The engagement strategy was also to try and engage with public figures to 
encourage them to also promote the work. This included videos ${ }^{5}$ with comedians Marcus Brigstocke and Robin Ince, the then UK Secretary of State for Energy and Climate Change Ed Miliband, who visited the exhibit at Latitude festival and then MP for Leicester South and Peter Soulsby, who attended Summer Sundae as a peer educator for a day.

Interviews and post-exhibit surveys were key features of the public engagement evaluation, beginning with a survey of adults and children $(n=198)$ attending the 2001 Walesby International Woodcraft Folk Festival (Devine-Wright et al., 2004). Woodcraft Folk children, compared to nonWoodcraft Folk children, felt they had more personal responsibility to conserve energy and use renewables, although there was no significant difference between the samples in their awareness of the practical steps that could be taken to reduce global warming.

The C-Change evaluation (White, 2011) consisted of: a before and after comparison of attitudes, a comparison to a national baseline of attitudes and a template analysis of qualitative data collected from attendees. This included audience surveys collected at Glastonbury in $2007(n=124)$. The results showed that general awareness of climate change was high, so interventions should instead aim to address attitudes. They suggest future projects should use peer education and fun interventions as these had influenced attitudes positively. To acknowledge the fact that people may be confused, fearful and concerned, messages should avoid creating negative feelings as these could lead to apathy, potentially in both peer educators and the audience.

1,361 audience questionnaires were completed in the EPSRC funded part of the project $(n=504$ in $2009, n=857$ in 2010). It confirmed that the project attracted a young audience, $80 \%$ were younger than 30 in 2010 . The audience was educated to a similar level as the background population, $30 \%$ with an undergraduate degree in any subject, and $12 \%$ with a degree in a science-related subject. In 2009 , of the respondents who were current students, $33 \%$ said as a result of participation they would now be more likely to consider a career or further education in science or engineering.

\footnotetext{
${ }^{5}$ Videos of these individuals and the project in general can be seen here: $\underline{\text { https://vimeo.com/user4385100 }}$
} 
Overall, the exhibit seemed to reach a very different audience to that of a typical science festival. A survey of the Cambridge Science festival found that $62 \%$ of the audience $(n=957)$ had an undergraduate or higher degree in any subject (Jensen \& Buckley, 2012), over twice the level of a music festival audience. In terms of age range, $34 \%$ were found to be 30 or younger at the science festival, whereas this compares to $80 \%$ of the music festival audience. Questionnaires completed by the audience after engagement with the exhibit in 2014-15 ( $n=179)$ showed that most agreed the peer educators were enthusiastic and well informed ( $98 \%$ and $94 \%$ agree respectively) and a significant number claimed they had increased their science and engineering knowledge (68\% agree) Research on electricity consumption at festivals began in2009. Temporary electrical power supply for outdoor events is principally concerned with cost and security of supply over environmental impact. Monitoring of generators identified potential greenhouse gas emission reductions of up to $50 \%$ by better sizing and operation of generators resulting in a greatly increased industry understanding and new guidance to festival organisers (Marchini, 2013). Electricity generators and smart grid data formed a key element of the exhibition and directly linked issues of environmental impact to the festival audiences own immediate experience. Addressing the topic of generators was a novel issue for the general audience as sites are generally designed to hide these features as much as possible. As research detail increased, exhibition materials changed to reflect the particular host festival's actual electricity consumption data. This was used to present a case for "smart" systems at festivals, with a combination of renewable energy, diesel generator and battery storage combined with advice and guidance to users. These "smart" concepts were used to discuss how future electricity demand, supply and storage could be developed nationally, in local communities and in the home. 


\section{Conclusions}

The peer education approach increased the knowledge and experience of the young people themselves while also helping them understand the factors that affect attitudes and behaviours of festival goers. They developed a good understanding of complex concepts and were able to work together to explain these effectively to festival goers. Peer educators were challenged outside their comfort zones and found this to be very positive. Several of them now work in the energy and environmental sectors; for example with renewable energy SMEs, Government departments, Energy utilities and NGOs.

The project had a sustained development over a long period of time ( $>10$ years) compared to similar initiatives. The three-part approach of peer education, public engagement and research has been a strength, yet one that has not been without its own challenges due to varying funding requirements and the interdisciplinary nature of the project. It was difficult to measure the lasting effect of the peer education on festival goers, though their characteristics in terms of age and education level suggest that the project reached a different audience compared to a more traditional form of science engagement. Festival goers enjoyed the experience and the relatively complex level of science and engineering was not felt to be out of place at a music festival.

Environmental education at music festivals has traditionally either not been addressed or only targeted at children. We have shown that it can be effectively delivered alongside normal festival activities if the right partners are in place and the peer educators receive the right support and training. The peer education approach, with training and multi disciplinary support from experts can be an effective instrument to discuss and develop environmental policy.

When the project started, renewable energy at outdoor events was relatively novel. Woodcraft Folk now routinely use renewable energy at their events and manage energy demand by encouraging the use of energy efficient equipment. This work contributed to guidance for festival organisers such as the Power Behind Festivals (Johnson et al., 2013) and Sustainable Event Management: A Practical 
Guide (Jones, 2014) and helped inform the Powerful Thinking Campaign ${ }^{6}$ that is helping festival organisers reduce their energy related carbon emissions.

The implications for Festival organisers are threefold. Firstly the project has shown that it is possible to increase people's knowledge of complex science and engineering issues about reducing greenhouse gas emissions as part of "normal fun activities"; secondly that face to face discussions with peer educators is an effective approach; and finally that festivals can reduce costs and greenhouse gas emissions by managing their electrical power provision more effectively, using more renewable energy and more hybrid generators.

The findings have implications for environmental education in general in terms of demonstrating that long term multi disciplinary partnerships and peer education can help deliver complex messages in partnership with key clients such as festival organisers.

\section{References}

Ajzen, I., (1991). The Theory of Planned Behavior. Organizational Behavior and Human Decision Processes, 50(2), 179-211.

Bandura, A. (1986), Social foundations of thought and action: A social cognitive theory. Englewood Cliffs, NJ: Prentice-Hall

Barr, S., (2006), Environmental Action in the Home: investigating the "value-action" gap. Geography, 91(1), 43-54.

\footnotetext{
${ }^{6}$ More information about the Powerful Thinking Campaign and further reports can be found here: http://www.powerful-thinking.org.uk/
} 
Bottrill, C. (2007), First Step: UK Music Industry Greenhouse Gas Emissions for 2007, (Rep.). London, UK: University of Oxford Environmental Change Institute \& Julies Bicycle

Challis, B. (2013, January 11). What fans want: green events and their fave band! Retrieved August 18, 2017, from http://www.agreenerfestival.com/2013/01/what-fans-want-green-events-and-theirfave-band/

Damon, W \& Phelps, E. (1989), Critical distinctions among three approaches to peer education. International Journal of Educational Research, 13(1) 9-19

Devine-Wright, P, Devine-Wright, H, Fleming, P. (2004), Situational influences upon children's beliefs about global warming and energy, Environmental Education Research, 10(4), 493-506

Department for Business, Energy and Industrial Strategy, (2016, June 1). Greenhouse gas reporting Conversion factors 2016. Retrieved August 18, 2017, from https://www.gov.uk/government/publications/greenhouse-gas-reporting-conversion-factors-2016 Donovan, C. (2013). A holistic approach to valuing our culture, (Rep.). London, UK: Department for Culture Media and Sport.

Fahy, F. (2005). The Right to Refuse: Public Attitudes and Behaviour towards Waste in the West of Ireland. Local Environment, 10(6), 551-569.

Fleming, P.D., Marchini, B. and Maughan, C. (2014) Electricity-related GHG emissions at off-grid, outdoor events. Carbon Management, 5(1), 55-65.

Fletcher, R. (2013). Five Capitals for festivals: integrated reporting of economic, social and environmental impacts (Discussion papers in Arts \& Festivals Management: DPAFM 2013/2), Leicester, UK: De Montfort University

Gardner, G.T. \& Stern, P.C., (1996). Environmental problems and human behaviour. Boston, MA: Allyn and Bacon. 
Getz, D (2010) Nature and scope of festival studies, International Journal of Event Management Research, 5(1), 1-47

Harper, P. (2010). Shambala Carbon: A (comprehensive) carbon footprint of Shambala Festival in 2010. (Rep) Powys, UK: Centre for Alternative Technology

Harper, P (2016), A Peoples History of the Woodcraft Folk, London: UK, Woodcraft Folk. House of Lords Select Committee on Science and Technology. (2002). Science and society, Third report, Chapter 5, 5.48

Jensen, E, and Buckley, N. 2014. Why people attend science festivals: Interests motivations and selfreported benefits of public engagement with research, Public Understanding of Science, 23(5), 557573 Johnson C, Marchini B, Botrill C and Tsiarta C. (2013). The Power Behind Festivals, (Rep.) Green Festival Alliance

Jones, M. (2014). Sustainable Events Management $2^{\text {nd }}$ Edition, London, UK: Earthscan Julie's Bicycle, (2014). Julie's Bicycle Benchmarks / Creative IG Tools: Benchmarks: Festivals (3 edition). Retrieved August 18, 2017, from http://www.juliesbicycle.com/services/ig-tools/juliesbicycle-benchmarks

Kollmuss, A. \& Agyeman, J. (2002). Mind the Gap: why do people act environmentally and what are the barriers to pro-environmental behaviour? Environmental Education Research, 8(3), 239-260.

Marchini, B. (2013). Festivals and Sustainability: Reducing energy-related greenhouse gas emissions at music festivals. (PhD Thesis). De Montfort University

Maughan, C, Fletcher, R. (2010). Summer Sundae Weekender festival evaluation, (Rep.) Leicester: UK, De Montfort University 
Müller, M. (2014). What makes an event a mega-event? Definitions and sizes. Leisure Studies, 34(6), 627-642.

Schwartz, S.H. (1977). Normative influences on altruism. In: L. Berkowitz, (Ed.) Advances in Experimental Social Psychology: Vol. 10, 221-279, New York, NY: Academic Press.

Stern, P.C. $2000^{\mathrm{a}}$. Toward a Coherent Theory of Environmentally Significant Behaviour. Journal of Social Issues, 56(3), 407-424.

Stern, P.C. $2000^{b}$. Psychology, sustainability, and the science of human-environment interactions. American Psychologist, 55(5), 461-478.

Stern, P.C., Dietz, T., Abel, T., Guagnano, G.A. \& Kalof, L. (1999). A Value-Belief-Norm Theory of Support for Social Movements: The Case of Environmentalism. Human Ecology Review, 6 (2), 81-97. Triandis, H.C. (1977). Interpersonal Behaviour. Monterey, CA: Brooks/Cole.

UK Music, (2017), Wish you were here 2017: The contribution of live music to the UK Economy, (Rep.) London: UK, Oxford Economics, UK Music

Wall, S. (2010). Involvement in a climate change youth engagement project: empowering the peer education experience; A grounded theory study exploring the effects of peer education interventions on peer educators participating in the Face Your Elephant project. (MSc Thesis). De Montfort University.

White, T. (2011). Climate change communications: Understanding people and evaluating the effectiveness of interventions. (PhD Thesis). De Montfort University. 


\begin{tabular}{|c|c|c|c|c|}
\hline Year / Funding & Festivals & Audience & $\begin{array}{l}\text { Numbers } \\
\text { engaged }\end{array}$ & Survey Data collected \\
\hline $\begin{array}{l}2001 \text { Energy } \\
\text { Saving Trust }\end{array}$ & $\begin{array}{l}\text { Woodcraft Folk (WF) } \\
\text { Sust'n'Able }\end{array}$ & 5,000 & 1,000 & $\begin{array}{l}\text { Survey of adults and children: } \\
n=198 \text {. }\end{array}$ \\
\hline 2002 EPSRC & WF Venturer camp & 500 & 500 & \\
\hline 2005 & WF Venturer camp & 700 & 700 & \\
\hline 2006 EPSRC & WF Global village & 5,000 & 1,000 & Audience surveys: $n=446$ \\
\hline 2007 DEFRA & Glastonbury & 150,000 & 1,000 & Audience surveys: $n=124$ \\
\hline $\begin{array}{l}2009-2010 \\
\text { EPSRC }\end{array}$ & $\begin{array}{l}\text { Big session } \\
\text { Latitude } \\
\text { Summer sundae }\end{array}$ & $\begin{array}{l}4,000 \\
30,000 \\
7,000\end{array}$ & 3,0001 & $\begin{array}{l}\text { Audience surveys: } n=1,361 \\
\text { (See Appendix A) } \\
\text { Carbon calculators: } n=184\end{array}$ \\
\hline $\begin{array}{l}2014-2015 \\
\text { RAEng }\end{array}$ & $\begin{array}{l}\text { Latitude } \\
\text { Shambala }\end{array}$ & $\begin{array}{l}30,000 \\
12,000\end{array}$ & 3,000 & $\begin{array}{l}\text { Peer educator before/after } \\
\text { training surveys: } n=32 \\
\text { Audience surveys: } n=179 \\
\text { (See Appendix } B \text { ) } \\
\text { Trader interviews: } n=75 \\
\text { Carbon calculators: } n=56\end{array}$ \\
\hline
\end{tabular}




\begin{tabular}{|c|c|}
\hline Peers teaching peers: & $\begin{array}{l}\text { "I still feel I lack some knowledge in areas but we have a wonderful } \\
\text { combination [of people in the group], so I have definitely gained } \\
\text { knowledge from the others." }\end{array}$ \\
\hline $\begin{array}{l}\text { The music festival } \\
\text { audience: }\end{array}$ & $\begin{array}{l}\text { "I normally volunteer at a Science Centre, so I thought that I wouldn't find } \\
\text { public engagement too hard, as that's what I do there. It turned out to be } \\
\text { much harder here." }\end{array}$ \\
\hline $\begin{array}{l}\text { Peers (and audiences) } \\
\text { going on to further } \\
\text { education and work: }\end{array}$ & $\begin{array}{l}\text { "Being involved in the project has enthused me about working in } \\
\text { engineering - I previously had a narrow view as to what it would entail" } \\
\text { "I talked to a girl who wanted to do engineering or science at university } \\
\text { and she found a lot of info really useful for her school studies." }\end{array}$ \\
\hline Industry perceptions: & $\begin{array}{l}\text { "It has been good to talk about these issues, as they are often neglected } \\
\text { in the side of industry I'm in" }\end{array}$ \\
\hline
\end{tabular}




\section{Appendix A: Questionnaire template 1}

Before starting the questionnaire, are you happy to fill in the following details about yourself: Name, Age, Gender, Email address.

1. Below are a number of terms that relate to the environment. For each one, could you say if you were aware of the phrase before today? (Options: Yes, No, Unsure) Global warming, Climate change, Carbon dioxide, Carbon emissions, Climate change gases, Greenhouse effect.

2. Do you agree or disagree that the world's climate is changing? (Options, Agree strongly, Agree, Disagree, Disagree strongly, Unsure). If you have answered 'Agree strongly' or 'Agree' in the above question, please answer (b) and (c)

2b. To what extent do you think Climate Change is a result of human behaviour or natural changes?(Due entirely to human behaviour, due mainly to human behaviour, due mainly to natural changes, due entirely to natural changes, unsure)

2c. How soon do you think the world, the UK and you personally will be affected by Climate Change (Option to select: the World, the UK, You personally. Options: Already affected, will be affected in the next 5 years, will be affected in the next 6-20 years, will be affected in the next 21-50 years, will be affected in more than 50 years, won't be affected at all)

3. What do you think are the main causes of Climate Change? (Open text)

4. Below are several pairs of words that some people have used to describe their attitude to Climate Change. For each pair, could you tick which word best reflects your own opinion:

(Unhopeful/hopeful, Unmotivated/motivated, Positive/negative, Frustrated/Enthused)

5. In the future, how much impact do you think Climate Change would have on the following (Option to select: No impact, a little impact, some impact, a large impact, unsure. Options: Your holidays, your health, your safety and security, the economy in the UK, the weather in the UK)

6a. How much influence do you think the each of the following individuals and groups can have on limiting Climate Change (Options to select: No influence, a little influence, some influence, a large influence. Option: The UK government, Industry \& Business, Scientists and engineers, your local community, you personally.)

6b. If you have answered 'A little influence', 'Some influence' or 'A large influence' to the above question please describe steps you can take personally to reduce the effects of Climate Change.

7a. Please describe what you understand by Renewable energy and Energy efficiency.(Open text).

7b. Please give two examples of energy efficiency and renewable energy (Open text)

8. If you are a student would you consider a degree in science or engineering? (Yes or no)

9. Would you consider a job or career in science or engineering? (Yes on no)

10. How would you rate the Face Your Elephant exhibition? (Excellent, Good, Average, Poor) 
11. How might the FYE exhibition be improved? (Open text)

1

2

3

4

5

6

7

8

9

10

11

12

13

14

15

16

17

18

19

20

21

22

23

24

25

26

27

28

29

30

31

32

33

34

35

36

37

38

39

40

41

42

43

44

45

46

47

48

49

50

51

52

53

54

55

56

57

58

59

60 


\section{Appendix B: Questionnaire template 2}

FACE YOUR ELEPHANT QUESTIONNAIRE 2015

\begin{tabular}{|l|l|l|l|l|l|}
\hline \multicolumn{7}{|l|}{ Please mark your highest level of qualification in: } \\
\hline Any subject: & None & GCSE & A level & Undergraduate degree & Postgraduate degree \\
\hline $\begin{array}{l}\text { A science or } \\
\text { engineering } \\
\text { related } \\
\text { subject: }\end{array}$ & None & GCSE & A level & Undergraduate degree & Postgraduate degree \\
\hline
\end{tabular}

\begin{tabular}{|l|l|l|l|l|l|l|}
\hline & $\begin{array}{c}\text { Strongly } \\
\text { Agree }\end{array}$ & Agree & Neutral & Disagree & $\begin{array}{l}\text { Disagree } \\
\text { Strongly }\end{array}$ & $\begin{array}{l}\text { Don't } \\
\text { Know }\end{array}$ \\
\hline $\begin{array}{l}\text { I better understand the causes of climate } \\
\text { change }\end{array}$ & & & & & & \\
\hline $\begin{array}{l}\text { I have increased my science and } \\
\text { engineering knowledge }\end{array}$ & & & & & & \\
\hline $\begin{array}{l}\text { I better understand how I could reduce my } \\
\text { carbon footprint }\end{array}$ & & & & & & \\
\hline $\begin{array}{l}\text { I know more about science and } \\
\text { engineering careers and education choices }\end{array}$ & & & & & & \\
\hline $\begin{array}{l}\text { It's important to me that a festival is } \\
\text { environmentally friendly }\end{array}$ & & & & & & \\
\hline & & & & & & \\
\hline $\begin{array}{l}\text { The volunteer team were well informed } \\
\text { The volunteer team were friendly and } \\
\text { enthusiastic }\end{array}$ & & & & & & \\
\hline $\begin{array}{l}\text { I thought the exhibit as a whole was } \\
\text { enjoyable }\end{array}$ & & & & & & \\
\hline $\begin{array}{l}\text { I thought the exhibit as a whole was well- } \\
\text { organised }\end{array}$ & & & & & & \\
\hline & & & & & & \\
\hline $\begin{array}{l}\text { I know more about smart grids and smart } \\
\text { meters }\end{array}$ & & & & & & \\
\hline I know more about demand shaping & & & & & & \\
\hline $\begin{array}{l}\text { I know more about hybrid, solar and } \\
\text { battery systems }\end{array}$ & & & & & & \\
\hline $\begin{array}{l}\text { I know more about energy efficient } \\
\text { devices }\end{array}$ & & & & & & \\
\hline
\end{tabular}

\section{Please indicate your age}

\begin{tabular}{|l|l|l|l|}
\hline & Under 16 & & $45-59$ \\
\hline & $17-24$ & & $60-64$ \\
\hline $25-29$ & & $65-74$ \\
\hline $30-44$ & & 75 or over \\
\hline
\end{tabular}

\begin{tabular}{|l|l|l|}
\hline \multicolumn{2}{|l|}{ 4. Please indicate your gender } \\
\hline & Male & Female \\
\hline & Prefer not to specify \\
\hline & Prefer to specify myself: \\
\hline
\end{tabular}

Is there anything else in particular you learned? Please state:

Was there an activity or exhibit you particularly found enjoyable or informative? Please state:

Do you have any further comments about the exhibit? 
